\title{
Reflections on the Integration of Innovation and Entrepreneurship Education into the Teaching of Fashion Design
}

\author{
Fang $\mathrm{Yi}$ \\ Jilin Engineering Normal University, Changchun City, Jilin Province, China, 130000 \\ 434294631@qq.com
}

Keywords: Innovation and entrepreneurship; Costume design; Optimization measures

\begin{abstract}
The contemporary society develops fast, and market competition is growing. All walks of life require a large number of high-quality personnel. The major colleges and universities introduce innovative teaching ideas. Fashion design is different from other majors, and it has a strong epochal character and the trend of fashion, it is necessary to cultivate students' innovative ideas and innovative ability to improve the core competitiveness of fashion design students. In view of this, this study takes the innovative entrepreneurial education idea as the breakthrough point and states the concrete measures to integrate it into the fashion design major, promoting the education level of fashion design major, and brings high quality talented person with the innovation ability to the society.
\end{abstract}

\section{Introduction}

After the rapid development in recent years, China's fashion design education system has been improved, cultivating a large number of high-quality clothing design talents, promoting China's garment industry development and growth. Fashion design is not simply following the rules; it requires designers to innovate, which can stimulate consumer desire to consume only, improving product market competitiveness. In this context, the fashion design major is necessary to innovate and reform the existing education model, gives full play to the guiding role of entrepreneurship education, updates students' employment concept, cultivates entrepreneurial awareness and innovation ability and promotes its comprehensive quality improvement. This paper will discuss from this.

\section{The Analysis of the Necessity of Innovating Entrepreneurship Education}

Innovative education is to develop students' initiative, but entrepreneurship education is to cultivate entrepreneurial talent. Therefore, it can be said that innovation and entrepreneurship education itself is a kind of quality education, so its basic connotation is to cultivate students' creativity and entrepreneurial awareness, and train their basic entrepreneurial skills, cultivates innovative thinking and entrepreneurial ability of high-quality personnel. Its necessity is reflected in three points.

Market Needs. At present, China can only cultivate high-quality talents to improve the core competitiveness, which requires colleges and universities to cultivate high-quality talents with innovative spirit and entrepreneurial ability, meeting the needs of social development. China's garment industry develops fast, but in general lacks of sufficient innovative talents and clothing entrepreneurs lack of sufficient expertise and innovation. It is to meet market demand by strengthening innovation and entrepreneurship.

Self Needs. Contemporary college students have a strong demand for self-worth. And innovative entrepreneurship education can effectively meet this demand. Students can be good at their own areas of entrepreneurship development, with innovative ways to promote business development. Innovate Entrepreneurship Education can cultivate the comprehensive quality and ability of college students, cultivate students' personality and potential and make them adapt to social changes as soon as possible and realize self-worth.

The Employment Situation. With the social development and industrial restructuring, the 
apparel industry's needs for talent is changing, resulting in the employment of graduates in a lot of uncertainties, so independent entrepreneurship has become a new way of employment of graduates. Independent entrepreneurship is based on innovation and entrepreneurship education, so colleges and universities should change the educational philosophy, with effective combination of professional education and innovation and entrepreneurship education, and further tap the potential of student innovation.

\section{Measures of Integrating Creative Entrepreneurship Education into the Education of Fashion Design}

Improve the Quality of Fashion Design Teachers. The knowledge of the modern society is accelerating constantly. The content of fashion design course is also reforming. The teacher can only optimize the professional knowledge system according to the development of the times and knowledge replacement. The original professional knowledge system cannot meet the new teaching form. Fashion design teachers cannot be once and for all, and teachers should establish the concept of lifelong learning, and constantly optimize their own knowledge system, update knowledge, which is the main component of professional quality of teachers. In the new economic context, knowledge can be transformed directly into multi-disciplinary collaboration required by the economy. As a central discipline, the edge disciplines of clothing design often intersect with adjacent disciplines, which requires the fashion design teachers not only having a solid professional knowledge, educational ideas and knowledge of education and practical knowledge, but also needing to master the related knowledge of fashion design expertise in the university at the same time, understanding the source of knowledge and dynamic evolution, and developing students' vision and thinking teaching through innovative entrepreneurship education with cutting-edge technology convergence.

A necessary basis for the implementation of innovation and entrepreneurship education is high-quality teacher's team system, which plays an important role in the course of teaching materials development and usage of teaching methods, etc. In order to carry out innovation and entrepreneurship education better, teachers need to improve their personal business level. Entrepreneurial experience, entrepreneurial knowledge and entrepreneurial ability are the content all teachers must have, and only in this way, the corresponding case analysis can be introduced into the teaching process. Their innovative entrepreneurial thinking can be stimulated out through personal experience. First of all, we must vigorously train entrepreneurs, improve the supporting incentive system, and regularly appoint some teachers to participate in entrepreneurial practice. In addition, some seniors, entrepreneurs, etc. can be hired, for part-time teaching work. At the same time, innovation and entrepreneurship practice should be innovated and richened, and academic exchanges should be actively carried out. Only the teacher team system is well built, the implementation of innovative entrepreneurship education curriculum can be guaranteed.

Integration of Professional and Innovative Entrepreneurship Education. With the development of market economy, in order to ensure that clothing and apparel design majors to better adapt to social development, colleges and universities need to give full attention to the entrepreneurship education. In the past, people understand the creation of garment enterprises as entrepreneurship, which is very unfavorable to the development of students' entrepreneurship education. In fact, whether it is to create new enterprises or to carry out innovative activities in existing garment enterprises, all of these belong to the business category. They exist in various organizations and business activities. Therefore, in order to ensure the smooth development of entrepreneurship education. Thus, they should be combined with the development of the times, timely updating the concept of entrepreneurship education. At the same time, in the teaching of clothing education in colleges and universities, there are too much emphasis on the cultivation of students' employment and self-employment, and the cultivation of students' independent entrepreneurship is deliberately ignored, which is very unfavorable for the future development of students and comprehensive quality training. When the colleges and universities cultivate clothing and apparel design talents, the actual characteristics should be combined. This backward and 
outdated entrepreneurial education concept should be actively reformed; social entrepreneurship education development direction should be reasonably grasped, to cultivate the comprehensive talents with both high design ability, the level of technology and a certain degree of marketing management capabilities. In addition, colleges and universities can also be based on their actual situation, set up business elective courses, interpenetrating the mutual knowledge of professional knowledge, and vigorously developing students' entrepreneurial skills and entrepreneurial theory.

Combination with the Actual Construction of the Curriculum System. Before making the training program of fashion design major, the market demand and the quality of clothing design students should be learned. According to this necessary quality of these positions, the core curriculum is developed, and the professional curriculum system that can support the core curriculum should be built with such basis. In this way, THE curriculum system of costume design major courses can be built, and the system can be divided into the public basic course, the core major curriculum, the support curriculum and the quality development curriculum. Each part should follow the professional requirements to design specific curriculum standards, implementation programs and follow-up courses to cultivate the application talent based on the construction of a sound curriculum system.

Now the employment pressure of college students is more and more. In pro graduation, in addition to coping with the normal burden of courses, but also they need to prepare take part in the postgraduate entrance exams, look for work and other matters. At the same time, most colleges and universities will also arrange the accounting practice in this period of time, which enough to see this stage is the most important and critical period for students, but also the stage with the most arduous. If students lack practical exercise, it will not only affect the students' comprehensive ability and quality, reduce the students' employment competitiveness, but also have a huge impact on the future development and employment of students. Therefore, colleges and universities should do a good job of assessment work of clothing design professional curriculum, establish a perfect assessment criteria to ensure that each student can participate in practical courses in the practice of teaching to fully develop their own comprehensive ability to ensure that the school can achieve the established teaching effect and students can improve their practical ability to operate.

Integration of production, study and research; practice is a major feature of entrepreneurship education, by guiding students to use knowledge and skills, to promote their own comprehensive ability improving. In the implementation of entrepreneurship education, the practice activity is a very important part. A well-known fashion design master once said, practical value embodied the effectiveness of clothing, and clothing value was measured through the market. Then also this rule is also needed to carry out clothing professional education. In the clothing education process, the requirements of the times development should be combined to implement the integration of production, study and research method. In the practice of teacher curriculum education, the methods of richening teaching means, comprehensive use of case analysis, field visiting can promote students to have scientific understanding of the whole process, and this method is more intuitive, so students' interest can also be significantly enhanced. In addition, other practical activities can assist, including encouraging students to participate in entrepreneurial competition, and carry out entrepreneurial association activities. Through the development of these activities, the learning knowledge and practice can be combined organically. Students can be organized to visit the entrepreneurial enterprise industrial park, to truly feel the clothing business cluster atmosphere with more profound understanding of the enterprise development process, mastering start-ups business management knowledge. So that the entrepreneurial interest of students can be cultivated, the entrepreneurial experience of students can also be enhanced, but also the knowledge of entrepreneurship and entrepreneurial skills can be effectively tested.

Innovative Teaching Rating System. For a long time, the costume design performance assessment model is relatively simple, with often using closed book examination method, and the teacher determine the degree of mastering the knowledge of clothing design according to the exam results of students. This method of assessment itself cannot stimulate students' interest in fashion design. Some students have weak practice ability, and only memorize theoretical knowledge. They 
get a higher score in the exam, which is not fair for the students with strong practice ability. Therefore, clothing design teachers should change the assessment model, combining the training model to assess the usual academic performance. The final results should be the final exam result combined with the usual results. The usual performance evaluation should include check-in, classroom status, and experimental results and so on. The students should be conducted a comprehensive assessment and supervision, to promote the practical ability of students to improve. If the teachers want to successfully use a wide range of evaluation methods, they must in-depth understand this approach with flexible use and ensure fair and impartial evaluation. Some questions can be set in the feedback form to guide students to try a variety of methods or team work to complete the task. They can also complete the communication through the instant messaging software. Teachers in the classroom focus on the job feedback, and taking it as part of the student's performance. Through the innovative teaching evaluation system, students feel the pressure in the daily study and slowly develop good learning habits and ways of thinking, unknowingly improve the professional quality.

Depth Cooperation between Universities and Enterprises. Colleges and universities should cooperate with the social enterprises to provide students with a wealth of practical opportunities. This model of cooperation not only can provide students with practical platform to cultivate students' practical ability, but also can transport the talents combining theory and practice to achieve a win-win situation. School-enterprise cooperation allows students to apply theoretical knowledge to specific work. Through the enterprise internship, etc., the students can accumulate rich social experience to lay a solid foundation in improving the competitiveness in the workplace; secondly, students combine professional characteristics with the business conditions, appropriately adjusting their own teaching materials, and strengthening the practicality of professional teaching materials, and the relevance of the actual business. The teaching group can adjust the teaching content and order in a macro-level, and it is easier for the teachers to integrate the ideas, methods and scientific research progress into the teaching activities. Through a series of interlocking scientific questions in the classroom, the students can understand the logical analysis of scientific research process, which is more appealing than knowing the answer itself. This kind of classroom design not only deepens the students' memory of basic knowledge, but also helps students understand the inherent nature of things, and have self-prediction and ideas for possible emerged scientific problems through the gradual analysis of the problem.

\section{Conclusion}

All in all, China's college students are facing enormous employment pressure, and colleges and universities ease the employment pressure with innovative entrepreneurship education. By the introduction of innovative ideas, fashion design professional education improves the quality of college students, with a substantial increase in employment rate of graduates. In this situation, colleges and universities should clearly understand this point, to improve the degree of emphasis on innovation and entrepreneurship, combining with their actual situation to explore the innovative entrepreneurial education model that meets their own characteristics, to transport a large number of high-quality clothing design talents to the society, and promote clothing industry sustainable development.

\section{References}

[1] G Guo, The Impact of Central Plains Folk Culture on the Teaching Construction of Costume Design Major [J]. Popular Arts .2016 (12): 11.

[2] F.X Liu, Teaching Research and Exploration of Applied Talents in Garment and Costume Design in Colleges and Universities [J]. Journal of Changchun Institute of Technology (Social Science Edition) .2015 (01): 47. 
[3] Z.X Ren, Reform and Practice of Costume Design Curriculum [J]. Youth Years .2016 (17): 123.

[4] H.H Zhang, W.H Yu, Research on the Training Model of Application Talents for Garment Based on Product-Taking Clothing and Costume Design Major of Hubei University of Science and Technology as an Example[J] Journal of Hubei Institute of Technology (Humanities and Social Sciences Version) .2016 (02) ): 62.

[5] X.H Shao, J Wen, Establishment and Reform of Garment and Costume Design Major Luggage Design Course [J]. Textile Industry and Technology .2016 (05): 73.

[6] Q Liu, X.M Cheng, Professional Innovative Talent Training Mode Thinking of Clothing and Apparel Design in New Era [J] .Technology and Education (late version) .2016 (07): 84.

[7] [7] Y Zhang, Reform and Innovation of Clothing and Apparel Design Professional Training Model, Taking Liaoning Institute of Media as an Example [J]. Art Education .2016 (11): 112.

[8] J Wang, School-Enterprise Cooperation Talent Training Mode of Clothing and Costume Design Major [J]. Art Education .2015 (12): 63.

[9] J.X Huang, Clothing and Costume Design Professional Practice Education Model [J]. Science and Technology Guide .2016 (07): 74.

[10] Y.Z Sun, Study on " $3+1$ ” Cultivating Model Based on Clothing And Apparel Design Major [J]. Liaoning Silk .2015 (01): 86.

[11]X.X Gao, Study on the Cultivation of Innovative Entrepreneurship Ability of Fashion Design and Engineering Major in Newly Built Undergraduate Colleges [J]. Rural Economy and Technology .2016 (18): 112.

[12] J.M Zhang, Thinking on People's Learning And Spiritual Pursuit [J]. Enterprise Herald .2014 (23): 123-125.

[13]X.Z Xu, Mei Weihui, Ni Hao. College Students' Entrepreneurial Difficulties and Institutional Innovation [J]. China Higher Education Research .2015 (01): 81. 